\title{
Human endometrial morphology around the time of implantation in natural and artificial cycles
}

\author{
T. C. Li $^{1}$, M. A. Warren ${ }^{2}$, P. Dockery ${ }^{2}$ and I. D. Cooke ${ }^{1}$ \\ ${ }^{1}$ Department of Obstetrics and Gynaecology, University of Sheffield, Jessop Hospital for Women, \\ Sheffield S3 7RE, UK, and ${ }^{2}$ Department of Biomedical Science, University of Sheffield, \\ Sheffield S10 $2 T N, U K$
}

\section{Introduction}

Grosser (1910) stated that the most important physiological function of the endometrial cycle is the preparation for the reception of a fertilized ovum (implantation), while menstruation is only a secondary process, a degeneration of the 'mucus membrane' which has not been able to fulfil its purpose. From the earlier work of Hertig et al. (1956), it is thought that implantation starts $\sim 6$ days after ovulation. Croxatto et al. (1978) found that, in the natural cycle, the human embryo usually arrives in the endometrial cavity $96 \mathrm{~h}$ or more after the luteinizing hormone (LH) surge. In most in-vitro fertilization programmes, fertilized embryos are transferred to the endometrial cavity a day or two earlier, which is still compatible with successful implantation. In artificial cycles, the transfer of embryos to the endometrial cavity between Days 17 and 19 has been reported to result in successful pregnancy.

In this paper, the morphology of the human endometrium in the periimplantation period of the natural and artificial cycles will be discussed, with emphasis on the steroidal requirement for normal endometrial development.

\section{Strategies for sampling endometrial tissue for morphological study}

We obtained biopsy specimens of the endometrium by an outpatient procedure without the need for anaesthesia. The techniques and complications of outpatient endometrial biopsy have been reviewed (Li et al., 1990a; Li \& Cooke, 1990a; Li \& Cooke, 1990b). We used the Sharman's biopsy curette (Down's Surgical Ltd, Sheffield, UK) to obtain the specimen because it is essential that the sample is of adequate size and intact. We have tried several other techniques of endometrial tissue sampling but the quality of sample obtained was not as good as with the Sharman's biopsy curette.

The sample should always be obtained from the upper or fundal part of the uterus, as the lower or isthmic part is structurally different from the upper part.

The collection of the endometrial sample should be precisely timed according to the LH surge, as it has been shown ( $\mathrm{Li}$ et al., 1987) that timing by this method is better than that based on the onset of the next menstrual period.

To reduce undue shrinkage of the tissue during fixation, the sample should be supported by pinning onto a piece of wax as soon as it is collected; a more gentle fixative, e.g. glutaraldehyde (which is in any case essential for ultrastructural studies), is preferred to formalin.

To optimize the results of any morphometric analysis, the section should be cut as thinly as possible. For this reason, we embedded our specimens in a plastic medium, JB-4 (Polysciences, Inc., USA) which enabled sections of $1-2 \mu \mathrm{m}$ to be cut; in contrast, the thickness of paraffin-embedded sections is $\geqslant 5 \mu \mathrm{m}$. 
Two methods may be used to study the morphology of the endometrium. The traditional method involves a set of subjective criteria proposed by Noyes et al. (1950) and measures only the overall maturity (histological dating); those with experience take only a few minutes. Another method, morphometry, involves quantitative measurements of individual histological features; this method is more objective and the results are more informative, but it takes longer.

\section{Natural cycle}

By the time the human embryo enters the endometrial cavity, $\sim 4$ days after the LH surge (Day $\mathrm{LH}+4)$, the glandular epithelial cells have accumulated large amounts of intracellular secretory materials (Fig. 1a). By Day $\mathrm{LH}+6$, most of these secretory products have been discharged into the gland lumen. Teleologically, these secretory materials should have functions related to implantation, although their precise roles are unknown. They may be involved in the nourishment of the blastocyst, i.e. in histiotrophic nutrition (Finn, 1977; Johnson \& Everitt, 1984). There is little information on the morphological changes of the luminal epithelium of the human endometrium around the time of implantation, or how the implanting human blastocyst goes through the luminal epithelium to reach the stroma. Presumably, the tight junctions at the apices of luminal epithelial cells have to be broken down to make a passage for the blastocyst. It is still a matter of debate as to the extent to which apoptosis, or programmed cell death, is involved in this process (Finn, 1977). We have observed apoptotic cells in the luminal epithelium around the time of implantation.

In the stroma, typical changes include the appearance of stromal oedema (Fig. 1b), proliferation of blood vessels and the decidual reaction (Fig. 1c). In the human endometrium, these changes begin around Day $\mathrm{LH}+8$, regardless of whether a blastocyst is present or not. In mice, decidual transformation only takes place in the presence of an adequately primed endometrium and a stimulus to the surface of the uterine epithelium by the trophoblast, although this can be replaced under experimental conditions by an artificial stimulus, such as a drop of oil (Finn \& Keen, 1962). From their morphological appearance, the decidual cells appear to be actively engaged in the synthesis of certain substances. They have been shown to produce a number of endometrial and placental proteins (for review, see Bell, 1986) and synthesize enzymes such as alkaline phosphatase (Wilson, 1969). The decidual tissue has been considered to play a role in restraining the invasiveness of the conceptus (Johnson \& Everitt, 1984).

The mechanisms of implantation and the relative roles of the blastocyst and the endometrium in implantation differ considerably in species. We do not know much about the mechanism of implantation in man, e.g. whether the closure reaction, the first stage of implantation observed in mice (Pollard \& Finn, 1972), exists in man. We know that the trophoblast appears to burrow actively between the luminal epithelial cells and that the luminal epithelium appears undisturbed (Finn, 1985; Edwards \& Fishel, 1986). Once the blastocyst is inside the endometrium, the uterine glandular tissue and the stromal tissue most adjacent to the invading blastocyst is destroyed. This releases large quantities of primary metabolic substrates which are then taken up by the blastocyst for growth and development. Later, the maternal blood vessels are also eroded, with the result that

Fig. 1. Morphological features of the endometrium in the periimplantation period of the natural cycle: (a) glandular epithelium from a normal woman at Day $\mathrm{LH}+4$ showing prominent basal vacuoles of secretory material $(\times 960)$; (b) view of stroma between glands in a normal woman at Day $\mathrm{LH}+8$. The stromal cells appear well-dispersed, probably due to oedema, which is maximal at this time $(\times 960)$; (c) electron micrograph taken from the stroma of a normal woman at Day $\mathbf{L H}+12$. A vessel, containing two red blood cells, is becoming surrounded by stromal cells. The 'decidualization' process is typical of this stage in the normal cycle $(\times 4100)$. 
(a) $\quad$ (a) (2) Fis A

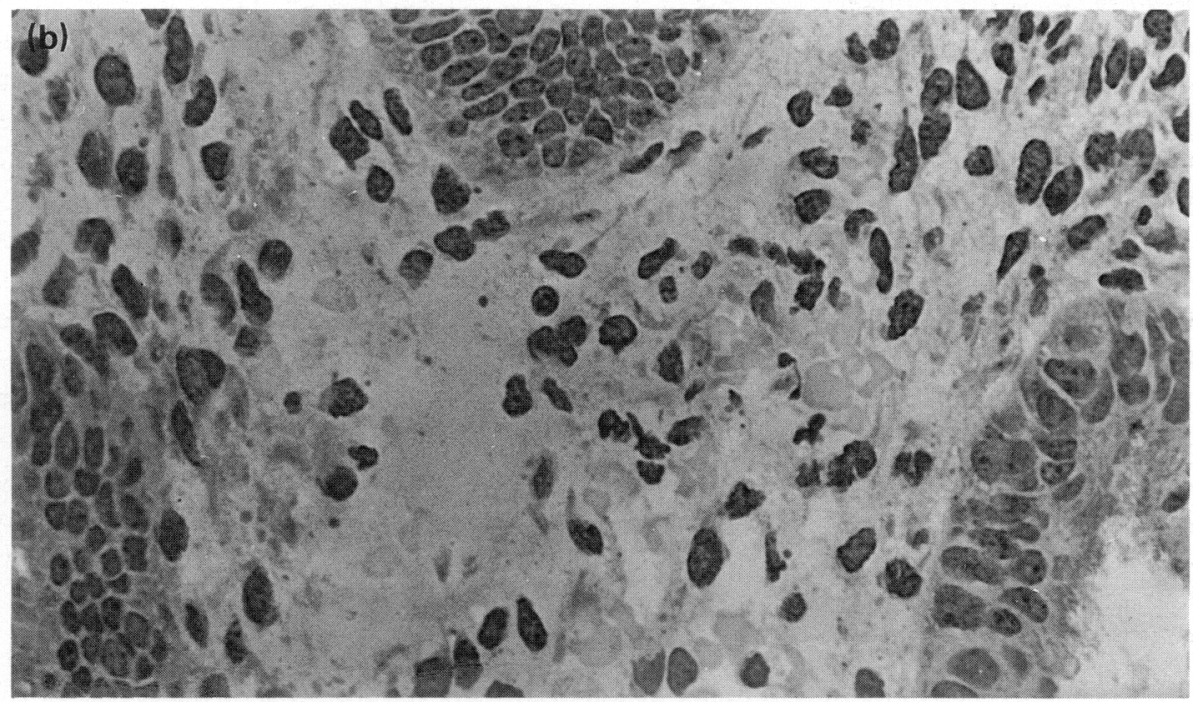

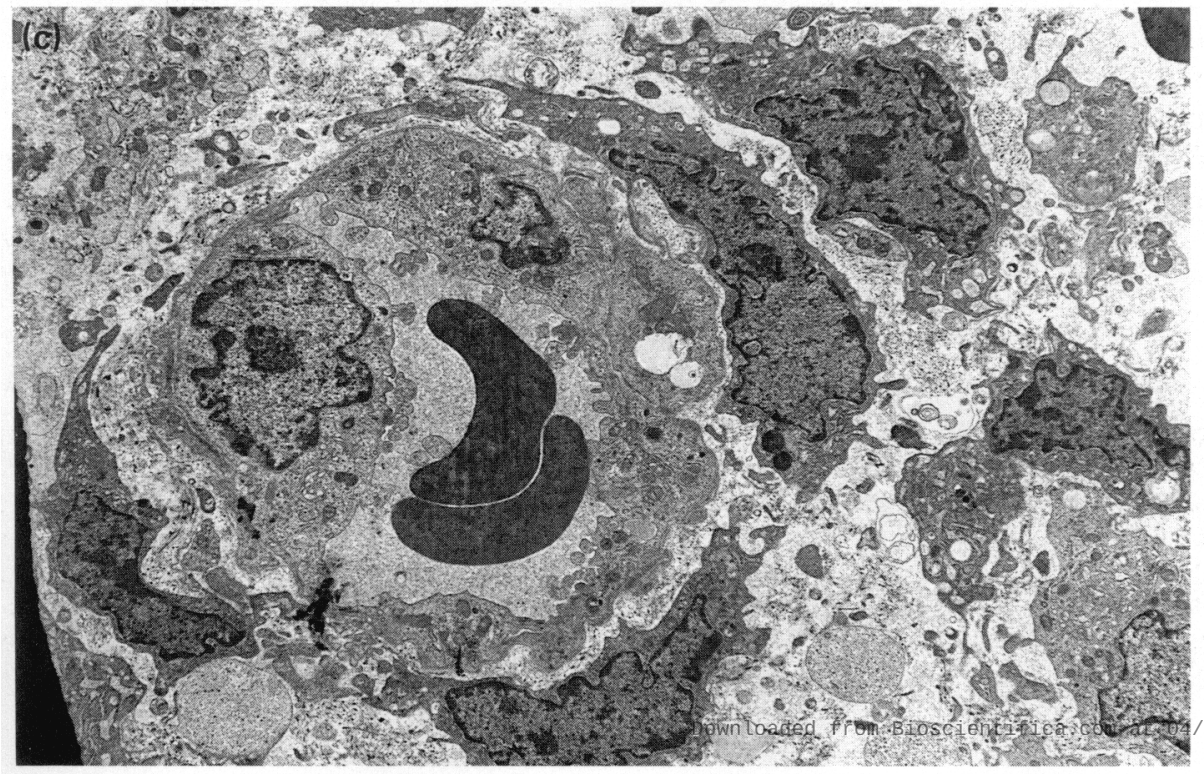


Table 1. Age, duration of infertility and the prevalence of retarded endometrial development among four groups of infertile women and a group of normal fertile women

\begin{tabular}{|c|c|c|c|c|c|}
\hline \multirow[b]{2}{*}{$n=$} & \multicolumn{4}{|c|}{ Type of infertility } & \multirow[b]{2}{*}{$\begin{array}{l}\text { Group V } \\
\text { (normal) } \\
68\end{array}$} \\
\hline & $\begin{array}{c}\text { Group I } \\
\text { (tubal) } \\
34\end{array}$ & $\begin{array}{c}\text { Group II } \\
\text { (male) } \\
39\end{array}$ & $\begin{array}{c}\text { Group III } \\
\text { (endometriosis) } \\
21\end{array}$ & $\begin{array}{c}\text { Group IV } \\
\text { (unexplained) } \\
48\end{array}$ & \\
\hline Age (years) & $\frac{3 \cdot 25 \pm}{\mathrm{NS}} 4 \cdot 0$ & $\begin{array}{c}30 \cdot 8 \pm 4 \cdot 0 \\
\mathrm{NS}\end{array}$ & ${ }_{\mathrm{NS}}^{34 \cdot 0 \pm 2 \cdot 9}$ & ${ }_{\mathrm{NS}}^{32 \cdot 7 \pm 4 \cdot 4}$ & $33 \cdot 4 \pm 4 \cdot 0$ \\
\hline $\begin{array}{l}\text { Duration of infertility } \\
\text { (years) }\end{array}$ & $6 \cdot 1 \pm 3 \cdot 3$ & $\begin{array}{l}6 \cdot 8 \pm 2 \cdot 7 \\
\text { NS }\end{array}$ & $\begin{array}{c}6 \cdot 9 \pm 2 \cdot 9 \\
\mathrm{NS}\end{array}$ & $\begin{array}{l}6 \cdot 0 \pm 3 \cdot 3 \\
\mathrm{NS}\end{array}$ & \\
\hline $\begin{array}{l}\text { Prevalence of retarded } \\
\text { endometrium } \\
\text { (histological dating } \\
\text { by traditional criteria) }\end{array}$ & $\begin{array}{c}1 / 34=2 \cdot 9 \% \\
\text { NS }\end{array}$ & $\begin{array}{c}3 / 39=7 \cdot 7 \% \\
\text { NS }\end{array}$ & $\begin{array}{c}6 / 21=29 \% \\
P<0 \cdot 01\end{array}$ & $\begin{array}{c}10 / 48=21 \% \\
P<0.01\end{array}$ & $3 / 68=4 \cdot 4 \%$ \\
\hline
\end{tabular}

Data (except prevalence of retarded endometrium) are means \pm s.d.

The results in the four groups of infertile subjects are compared individually to the normal fertile subjects by two sample $t$ tests or $2 \times 2$ contingency table analysis.

NS $=$ not significant.

the trophoblastic cells are bathed in maternal blood, and finally haemotrophic support of the conceptus is established.

Recently, more refined, quantitative data on endometrial morphology in the periimplantation period have been obtained on precisely timed specimens from fertile subjects (Johannisson et al., 1982; Johannisson et al., 1987; Li et al., 1988a; Dockery et al., 1990). Dockery et al. (1988) found a small intersubject variation in the morphology of endometria obtained between Days $\mathrm{LH}+2$ and LH +5 from normal, fertile subjects; the results suggest that cellular events during this period are tightly controlled.

\section{Endometrial morphology of infertile subjects}

We compared endometrial development in the luteal phase of fertile and infertile subjects and found that the prevalence of retarded endometrial development (histological dating based on the criteria of Noyes et al., 1950, more than 2 days behind chronological dating based on the LH surge) in the infertile population $(20 / 142=14 \%)$ was significantly higher than in the fertile population $(3 / 68=4.4 \%)$. However, when the infertile subjects were subdivided into groups of different aetiology, women with endometriosis and unexplained infertility had significantly higher prevalence of retarded endometrium than women with normal fertility; the prevalence in women of infertility associated with tubal or male infertility was not significantly different from that of the fertile subjects (Table 1).

We examined the endometrial morphology in those with unexplained infertility by morphometric techniques ( $\mathrm{Li}$ et al., 1990b) and found that the abnormalities were all related to the glandular, but not the stromal, component of the endometrium (Fig. 2). Immunohistochemical study of these specimens using monoclonal antibody D9B 1 confirmed that the secretory activity of endometrial glands in women with unexplained infertility was abnormal (Graham et al., 1990). Most of the women with abnormal endometrial development had normal progesterone concentrations, suggesting that abnormal response of the endometrium, rather than subnormal progesterone production, is a common cause of abnormalities in such cases. (Li et al., in 1990c).

\section{Endometrial response to antiprogesterone and progesterone}

We previously reported that the administration of a single dose of progesterone receptor blocker (mifepristone) in the periimplantation period (Days $\mathbf{L H}+2$ to $\mathbf{L H}+6$ ) resulted in 

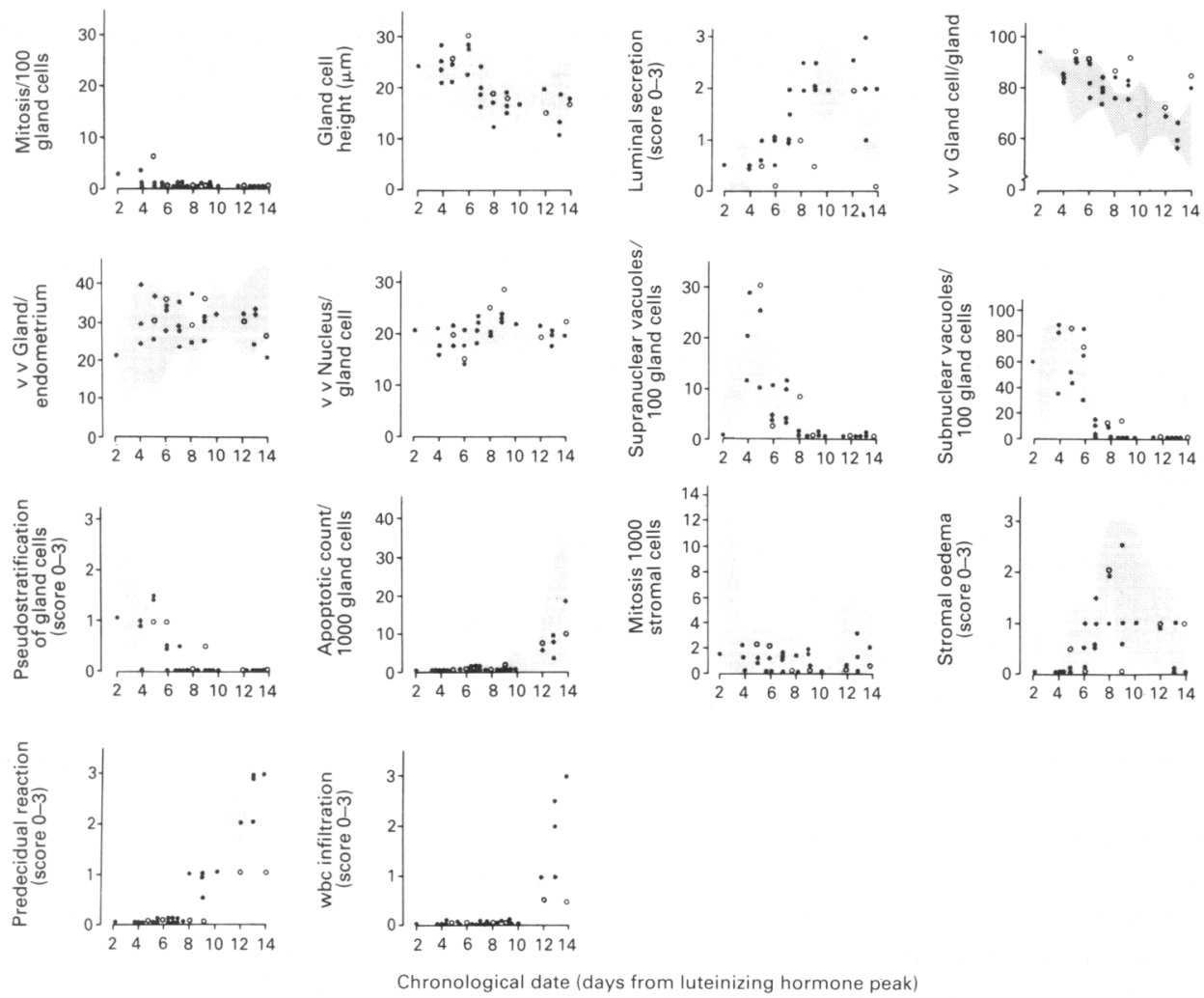

Fig. 2. Endometrial morphology in women with unexplained infertility $(n=30)$; the results of each individual morphometric measurement are shown on a background of the normal range (shaded area) established from a fertile population $(n=70) ;(\bullet)$ overall endometrial development (histological dating) is normal; $(O)$ overall endometrial development is retarded, $\mathrm{vv}=$ volume fraction of, $w b c=$ white blood cell. First published in British Journal of Obstetrics and Gynaecology, 1990.

profound changes in endometrial morphology, including the inhibition of glandular secretory activity, acceleration of degenerative changes, increased stromal mitosis, dilatation of venules and high stromal extravasation ( $\mathrm{Li}$ et al., 1988b). More recently, we examined the morphological response of normally developing endometrium $(n=8)$ to a single intramuscular dose of $100 \mathrm{mg}$ of progesterone administered between Days $\mathrm{LH}+1$ and $\mathrm{LH}+6$, by the use of morphometric techniques and transmission electron-microscopy (T. C. Li, unpublished data). We were unable to detect any significant effect of the administered progesterone on endometrial morphology. It is possible that a normally developing endometrium at this stage is already maximally stimulated by progesterone, so that the administration of a large dose of exogenous progesterone does not result in any further change. Perhaps, this is not surprising, considering the rapid changes of endometrial morphology in the first half of the luteal phase.

\section{Artificial cycle}

The artificial cycle refers to one produced in women with nonfunctioning or no ovaries, by the administration of steroid hormones, oestrogen and progesterone, in a sequential manner so as to mimic the natural cycle of normal, regularly cycling women. The artificial cycle provides a unique human model for studying the relationship between peripheral steroid hormones and the 
morphology and function of the endometrium, and to address critical physiological aspects of implantation, such as the implantation window and morphological markers of implantation.

\section{Intersubject variability of endometrial response in the artificial cycle}

In a recent study, we examined the variability of the endometrial response to a standard hormone replacement therapy (HRT) (Navot et al., 1986) in 18 women with premature ovarian failure, by serial ultrasonographic measurement of endometrial thickness and histological study of endometrial biopsy taken on Day 19 of the artificial cycle. Women with idiopathic premature ovarian failure $(n=10)$ had a significantly thicker endometrium and more-advanced histological development than women with Turner's syndrome $(n=4)$; whereas women with premature ovarian failure associated with previous chemotherapy had intermediate responses (Table 2). A previous study by Fraser et al. (1989) on the endometrial response of post-menopausal women to combined oestrogen and progestogen HRT also suggested wide intersubject variation. These observations suggest that women with (premature) ovarian failure should not be taken to represent a homogeneous population. A satisfactory response in some women to a HRT regimen may not necessarily imply the same in others. For this reason, in planning clinical trials involving the comparison of two or more HRT regimens, a cross-over design may be more appropriate than a cohort one, as the former reduces the variance of results due to individual difference in the response of the endometrium. While successful pregnancy in women with Turner's syndrome treated with HRT and donor oocyte has been reported (Salat-Baroux et al., 1988), it will be of interest to compare the pregnancy rate of women with Turner's syndrome participating in a donor oocyte programme, with that of women with other causes of premature ovarian failure, to determine whether the observed difference in endometrial development is of functional and prognostic significance.

\section{Oestrogen priming: is an incremental regimen necessary?}

The earlier HRT regimens for artificial cycles were designed to mimic the natural cycle and so the oestrogen was administered in a variable, incremental manner to reproduce an oestrogen surge in the late proliferative phase. However, whether such a surge is required for normal endometrial maturation is unclear. Serhal \& Craft (1987) suggested that the variable, incremental regimens could be simplified to a fixed oestrogen regimen throughout the artificial cycle; they subsequently reported successful pregnancies in women who received this type of HRT regimen (Serhal \& Craft, 1989). Cameron et al. (1989) reported that normal endometrial morphology was achieved in artificial cycles produced by a fixed, $2 \mathrm{mg}$ daily dose of oestradiol valerate.

These observations suggest that normal endometrial development is not dependent on the oestrogen surge in the late proliferative phase. This is in keeping with our previous observation in the natural cycle that endometrial development in the luteal phase was not related to the magnitude of the oestrogen surge (Li et al., 1990c).

In comparison with the variable, incremental regimen, the fixed dose regimen is simple and is likely to increase acceptability by patients and compliance. In a consecutive series of 20 women with premature ovarian failure prescribed the variable, incremental regimen in our clinic, two $(10 \%)$ reported mistakes in taking the correct dose of drugs; whereas none of 14 consecutive women who were prescribed the fixed dose regimen recorded any error.

\section{Optimum doses of oestrogen}

The serum oestradiol concentrations in artificial cycles produced by a number of HRT regimens, such as those of Navot et al. (1986), Lutjen et al. (1984) and Serhal \& Craft (1987), were higher than those of the natural cycle. In our studies, the serum concentrations of oestradiol in artificial cycles produced by the regimen of Navot et al. (1986) were 2-5 times those of the natural cycle. 
Preliminary data from our laboratory suggest that, although such high concentrations of oestradiol do not appear to produce any obvious abnormality under the light microscopy, features in keeping with excessive oestrogenic influence were detected by transmission electron microscopy (P. Dockery, unpublished data).

Analysis of results reported by other investigators revealed similar evidence of excessive oestrogen stimulation in the glands, such as persistence of subnuclear vacuoles (Borrero et al., 1989) and relative glandular retardation (Droesch et al., 1988). Perhaps further studies are required to define the optimal oestrogen doses for priming of the endometrium in artificial cycles.

\section{Duration of oestrogen priming}

Navot et al. (1989) studied the effect of variable duration of oestrogen priming and reported that endometrial development in the artificial cycle was similar in those with a short duration of priming ( 6 days), a standard duration of priming (2 weeks), or a long duration of priming (3-5 weeks). Their results suggested that the duration of oestrogen priming is likely to be flexible.

\section{Effect of varying doses of progesterone}

In a prospective, cross-over study, we examined the effect of various doses of progesterone on endometrial development in the artificial cycles (T. C. Li, unpublished data). The HRT of Navot et al. (1986) was used as a standard regimen, which involved oral administration of a variable daily dose (1-6 mg) of oestradiol valerate and intramuscular administration of 25-50 mg of progesterone in oil from Days 15 to 28 of the cycle. In the modified regimens, the doses of oestradiol valerate were unaltered but the doses of progesterone were increased to five times of the standard regimen, i.e. $125-250 \mathrm{mg}$ (high progesterone regime), or reduced to only one-fifth of the standard regimen, i.e. 5-10 mg (low progesterone regime). In all cycles studied, an endometrial specimen was obtained on Day 19 , i.e. on the 5 th day of progesterone therapy. While suboptimal doses of progesterone result in retarded endometrial development, large or supranormal doses of progesterone do not advance endometrial development. The minimal doses of progesterone required to produce normal endometrial development should lie somewhere between the standard and low progesterone regimens. These results are in agreement with the observations of Devroey et al. (1989), who reported that normal endometrial maturity in the midluteal phase (Day 21) of artificial cycles could be achieved with a rather wide range of serum progesterone concentrations (from $<10 \mathrm{ng} / \mathrm{ml}$ to $>30 \mathrm{ng} / \mathrm{ml}$ ). However, progesterone concentrations $\leqslant 5 \mathrm{ng} / \mathrm{ml}$ appeared to result in abnormal development.

Navot et al. (1989) attempted to address the question of whether secretory transformation in the endometrium of artificial cycles could be accelerated by high doses of progesterone. At a daily dose of $150 \mathrm{mg}$, progesterone did not advance endometrial development in the early luteal phase, but the authors claimed that endometrial maturation in the late luteal phase was accelerated. However, one criticism of their study is that endometrial samples were obtained 2 days earlier in the cycles treated with high doses of progesterone than those treated with standard doses of progesterone, 'because of the anticipated hastened secretory transformation'.

\section{Effect of different preparations of progesterone}

Oral progesterone. Dehou et al. (1987) reported that delayed endometrial maturation appeared typical of artificial cycles treated with oral progesterone at a daily dose of 300-600 mg: subnuclear vacuoles, nuclear channel systems and giant mitochondria were absent on Days 16 to 19, whereas pseudostratification and glandular mitoses were prominent. In contrast, cycles treated with intramuscular progesterone $(50-100 \mathrm{mg} /$ day) revealed normal glandular maturation, both at lightmicroscopic and electron-microscopic levels. Later, Devroey et al. (1989) compared the effects of $300 \mathrm{mg}$ of oral progesterone with those of $100 \mathrm{mg}$ of intramuscular progesterone and presented similar findings. In both of the above studies, serum progesterone concentrations were significantly 
lower in cycles treated with oral progesterone than in those treated with intramuscular progesterone, suggesting that a probable explanation of the difference was the poor absorption of progesterone when administered orally. Increasing the oral dose of progesterone may not be appropriate because of side effects, especially sleepiness (Devroey et al., 1989).

Vaginal progesterone. In artificial cycles treated with vaginal progesterone at $300-600 \mathrm{mg}$, Devroey et al. (1989) found that the histological and electron-microscopic pictures of the endometrium on Day 21 of the cycle were similar to cycles treated with intramuscular progesterone at a daily dose of $100 \mathrm{mg}$, although the serum concentrations of progesterone in cycles treated with intramuscular progesterone were five times higher than those treated with vaginal progesterone. (The serum concentrations of progesterone in the latter were, in turn, higher than those cycles treated with oral progesterone at the same dose.) Progesterone (micronized) administered vaginally has been reported to support implantation and pregnancy in artificial cycles (Devroey et al., 1989).

Dydrogesterone. Dydrogesterone (Duphaston) has been claimed to be useful in the treatment of luteal-phase defect (Balasch et al., 1982) and successful in inducing endometrial secretory changes in post-menopausal women (King \& Whitehead, 1986; Lane et al., 1986). However, a recent crossover study by Pellicer et al. (1989) comparing the use of dydrogesterone $(10-20 \mathrm{mg} / \mathrm{day}$, given orally) and progesterone administered intramuscularly $(25-50 \mathrm{mg} / \mathrm{day})$ in artificial cycles revealed out-of-phase endometrium in 3 of 8 cases treated with dydrogsterone, but in none of 8 cases treated with intramuscular progesterone. In addition, (a) stromal haemorrhagic suffusion and increased oedema were noted in the endometrium of all those treated with dydrogesterone and (b) the total protein content of uterine lavages $(10 \mathrm{ml}$ normal saline via a Foley catheter) was significantly lower in those treated with dydrogesterone than in those treated with intramuscular progesterone. It was, therefore, concluded that endometrium supplemented with dydrogesterone failed to result in optimal endometrial development and should not replace intramuscular progesterone as the progestin in steroid replacement cycles.

\section{Comparative studies of the natural and artificial cycles}

Comparative morphological studies of endometria obtained from various cycles known to be capable (or not capable) of supporting implantation may provide important information on which of the morphological features are consistently associated with normal function, i.e. implantation, and so may be used as marker(s) of implantation. We compared the morphology of endometrium in the periimplantation period in (a) natural cycles of women with proven fertility, and (b) artificial cycles of women with idiopathic premature ovarian failure receiving the hormone replacement regimen of Navot et al. (1986). In the artificial cycles $(n=12)$, all endometrial specimens were taken on Day 19, i.e. the Day 5 of progesterone therapy and this corresponds to Day $\mathrm{LH}+5$ of the natural cycle. The endometrial specimens were dated and further analysed by established morphometric techniques (Li et al., 1988a; Dockery et al., 1988, 1990). The results are shown in Table 2 and Fig. 3.

The results indicate that, while the HRT regimen of Navot et al. (1986) produced endometrial morphology similar in many aspects to the corresponding Day $(\mathrm{LH}+5)$ of the natural cycle, subtle differences in the stroma were detected by morphometry. The stromal cell dimensions (Fig. 3 ) are similar to those of Day $\mathrm{LH}+2$ from the natural cycles. However, the volume fraction of the total tissue (endometrium) occupied by the stromal cell nuclei is similar to the corresponding period (Days $\mathrm{LH}+4$ to $\mathrm{LH}+6$ ) of the natural cycle. When compared with the natural cycle, the smaller stromal cell nuclei but similar volume fraction (ratio) in the artificial cycle together suggest an increase in cell density, a finding which is supported by the earlier report of Dehou et al. (1987). Given that both these cycles are capable of supporting implantation, perhaps the stromal cell size and density are of little functional significance as far as implantation is concerned.

So far, many different HRT regimes have been reported to be capable of supporting implantation in the artificial cycle (Lutjen et al., 1984; Navot et al., 1986; Rosenwaks, 1987; Serhal \& Craft, 1987; 
Table 2. Endometrial morphology between Day 19 of artificial cycle, from 12 women with idiopathic ovarian failure receiving the hormone replacement therapy regimen of Navot et al. (1986) and Day $\mathrm{LH}+5$ of natural cycles from 8 previously fertile women

\begin{tabular}{lccc}
\hline Measurements & $\begin{array}{c}\text { Day 19 of } \\
\text { artificial cycle } \\
(n=12)\end{array}$ & $\begin{array}{c}\text { Day LH }+5 \\
\text { of natural cycle } \\
(n=8)\end{array}$ & $P$ value \\
\hline $\begin{array}{l}\text { Histological dating } \\
\text { (overali development) }\end{array}$ & $\begin{array}{c}4 \cdot 9 \\
(4 \cdot 1-6 \cdot 4)\end{array}$ & $\begin{array}{c}5 \cdot 3 \\
(3 \cdot 5-6 \cdot 7)\end{array}$ & NS \\
$\begin{array}{l}\text { Mitotic activity } \\
\quad 1000 \text { gland cells } \\
\quad 1000 \text { stromal cells }\end{array}$ & $0 \cdot 5(0-2 \cdot 0)$ & $0 \cdot 5(0-3 \cdot 0)$ & NS \\
$\quad \begin{array}{l}\text { Volume fractions (\%) } \\
\text { Gland occupied by gland cells }\end{array}$ & $86(67-89)$ & $85(71-93)$ & NS \\
$\quad$ Endometrium occupied by gland & $34(24-47)$ & $30(17-34)$ & NS \\
$\quad \begin{array}{l}\text { Secretory vacuoles/1000 gland cells: } \\
\quad \text { Supranuclear }\end{array}$ & $10(5-20)$ & $18(6-47)$ & NS \\
$\quad$ Subnuclear & $68(30-92)$ & $69(22-81)$ & NS \\
\hline
\end{tabular}

Results are medians, with ranges in parentheses NS, not significant, according to Wilcoxon nonparametric test.
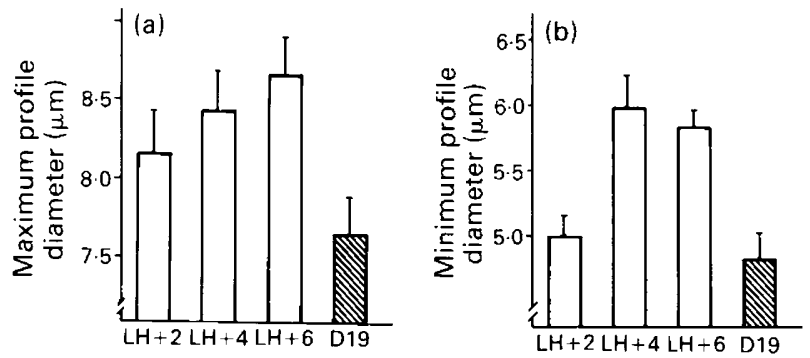

Chronological date (days from LH peak)

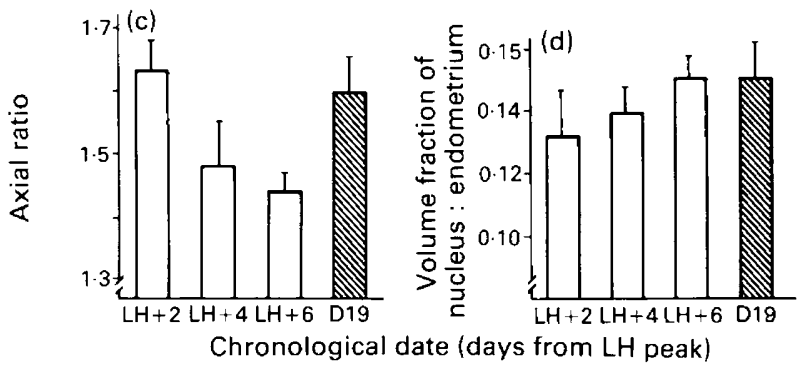

Fig. 3. Data on stromal cell nuclei ( $a, b$ and $c$ ) and endometrial stroma (d) in endometrial specimens obtained on Day (D) 19 of artificial cycles in 12 women with idiopathic premature ovarian failure receiving the hormone-replacement therapy regimen of Navot et al. (1986) $(\mathbb{\$})$, and endometrial specimens collected from the early luteal phase of natural cycles from 12 normal, fertile women $(\square)$. $\mathbf{L H}=$ luteinizing hormone. The data on the natural cycles have been published (Dockery et al., 1990). Each bar represents the result in arithmetic mean, each vertical line represents the s.e. 
Asch et al., 1988; Droesch et al., 1988; Devroey et al., 1989; Steingold et al., 1989; Ben-Nun et al., 1989). Among these regimens, the oestrogen may be administered orally as oestradiol valerate (Lutjen et al., 1984; Navot et al., 1986; Serhal \& Craft, 1987), micronized oestradiol (Rosenwaks, 1987; Asch et al., 1988), conjugated oestrogen, e.g. Premarin (Ben-Nun et al., 1989), or the oestrogen may be given via a vaginal ring (Rosenwaks, 1987; Steingold et al., 1989), or a transdermal patch (Droesch et al., 1988). The progesterone may be given intramuscularly (Lutjen et al., 1984; Navot et al., 1986; Asch et al., 1988) or via a pessary (Rosenwaks, 1987; Lutjen et al., 1986; Devroey et al., 1989). It seems that endometrial receptivity to embryo implantation could be achieved by a rather wide range of HRT regimens with various preparations of oestrogen and progesterone.

The Norfolk group of investigators (Rosenwaks, 1987; Droesch et al., 1988; Navot et al., 1989; Steingold et al., 1989) consistently reported on glandular stromal disparity (stroma more advanced than gland by $2-3$ days) in artificial cycles produced by various types of HRT regimens. However, we do not have the same experience with endometrial samples obtained on Day 19 of the artificial cycle. If there is a glandular stromal disparity, our data suggest that the stroma is relatively retarded, not advanced. Glandular stromal disparity in artificial cycles has not been reported by other investigators.

Among the various HRT regimens known to be capable of supporting implantation and pregnancy in artificial cycles, the overall endometrial development was reported to be normal in some (Navot et al., 1986; Lutjen et al., 1986; Hung et al., 1989), but retarded in others, e.g. by 2-3 days (Borrero et al., 1989). None reported on the advancement of endometrial development. These observations suggest that some degree of retardation of endometrial development may be compatible with successful implantation in the artificial cycle.

\section{Window of implantation and transfer}

It is generally agreed that a certain degree of synchrony is required between the arrival of the blastocyst at the site of implantation and the stage of development of the endometrium in order to achieve successful implantation (McLaren, 1984; Edwards \& Fishel, 1986). In rats and mice, there appears to be a narrow window during which implantation can be initiated and outside which implantation may not take place. In mice, for the first 2-3 days after fertilization, replaced embryos do not survive in the uterus. The ensuing $36-48 \mathrm{~h}$ is a period in which embryos could survive in the uterus, but implantation would not be possible. Then there is a narrow window of just a few hours during which implantation can occur. After this time, the uterine environment becomes hostile, and any unimplanted embryo degenerates (Psychoyos, 1961). Although the window of implantation is rather narrow, exact synchrony between endometrial and embryo development is not required, because during the $36-48 \mathrm{~h}$ prior to this window, the endometrium is not hostile to the developing embryo. It is possible for a more advanced embryo to remain dormant in a relatively retarded endometrium to allow the latter to catch up. The embryo needs to be at the same stage as, or slightly more advanced than, the endometrium; the embryo cannot afford to lag behind.

A similar window is thought to exist in man. From the study of Croxatto et al. (1978), in the natural cycle, the human embryo usually arrives in the endometrial cavity $96-120 \mathrm{~h}$ after the $\mathrm{LH}$ surge. In stimulated, in-vitro fertilization cycles, embryos often arrive in the endometrial cavity around Day $\mathrm{LH}+3$, i.e. 1-2 days earlier than the natural cycle, but implantation is still possible. In artificial cycles, experience from various centres with established donor oocyte programmes suggests that the embryos are best transferred to the endometrial cavity $2-4$ days after the commencement of progesterone therapy (Navot et al., 1986; Serhal \& Craft, 1987; Rosenwaks, 1987). Investigators in the Monash Centre, however, suggest transferring the embryo slightly earlier, 1-3 days after the start of progesterone therapy (Chan et al., 1987). On the whole, it seems likely that the window of transfer in man covers 3-4 days. 


\section{Conclusions}

The study of artificial cycles in women with premature ovarian failure has provided a unique human model for understanding the steroidal requirement for normal endometrial development and implantation. Clinically, highly rewarding results have been obtained as artificial cycles are now capable of supporting implantation. Comparative study of the natural and artificial cycles has resulted in a better definition of the implantation window, and will undoubtedly help to answer other important questions in reproductive biology, e.g. morphologiccal markers of implantation and embryo-endometrial interaction.

The authors are grateful to the late Professor A. W. Rogers for his contributions to some studies mentioned in this manuscript, and to Mrs M. Thorpe for her expert secretarial assistance.

\section{References}

Asch, R.H., Balmaceda, J.P., Ord, T., Borrero, C.B., Cefalu, E., Gastaldi, C. \& Rojas, F. (1988) Oocyte donation and gamete intrafallopian transfer in premature ovarian failure. Fert. Steril. 49, 263-267.

Balasch, J., Vanrell, J.A., Marquez, M., Burzaco, I. \& Gonzalez-Merlo, J. (1982) Dehydrogesterone versus vaginal progesterone in the treatment of the endometrial luteal phase deficiency. Fert. Steril. 37, 751-754.

Bell, S.C. (1986) Secretory endometrial and decidual proteins: studies and clinical significance of a maternally derived group of pregnancy-associated serum proteins. Hum. Reprod. 1, 129-143.

Ben-Nun, I., Ghetler, Y., Gruber, A., Jaffe, R. \& Fejgin, M. (1989) Egg donation in an in vitro fertilization program: an alternative approach to cycle synchronization and timing of embryo transfer. Fertil. Steril. 52,683687 .

Borrero, C., Remohi, J., Ord, T., Balmaceda, J.P., Rojas, F. \& Asch, R.H. (1989) A program of oocyte donation and gamete intra-Fallopian transfer. Hum. Reprod. 4, 275-279.

Cameron, I.T., Rogers, P.A.W., Caro, C., Harman, J., Healy, D.L. \& Leeton, J.F. (1989) Oocyte donation: a review. Br. J. Obstet. Gynaec. 96, 893-899.

Chan, C.L.K., Cameron, I.T., Findlay, J.K., Healy, D., Leeton, J.F., Lutjen, P.J., Renou, P.M., Rogers, P.A., Trounson, A.O. \& Wood, E.C. (1987) Oocyte donation and in vitro fertilization for hypergonadotrophic hypogonadism: clinical state of the art. Obstet. Glne'. Sury. 42, 350-362.

Croxatto, H.B., Ortiz, M.E., Diaz, S., Hess, R., Balmaceda, J. \& Croxatto, H.D. (1978) Studies on the duration of egg transport by the human oviduct II. Ovum location at various intervals following $\mathrm{LH}$ peak. Am. J. Obstet. Gynec. 132, 629-634.

Dehou, M.F., Lejeune, B., Arijs, C. \& Leroy, F. (1987) Endometria! morphology in stimulated in vitro fertilization cycles and after steroid replacement therapy in cases of primary ovarian failure. Fert. Steril. 48, 995-1000.

Devroey, P., Palermo, G., Bourgain, C., Van-Waesberghe, L., Smitz, J. \& Van-Steirteghem, A.C. (1989) Progesterone administration in patients with absent ovaries. Int. J. Fert. 34, $188-193$.
Dockery, P., Li, T.C., Rogers, A.W., Cooke, I.D. Lenton, E.A. \& Warren, M.A. (1988) An examination of the variation in timed endometrial biopsies. Hum. Reprod. 3, 715-720.

Dockery, P., Warren, M.A., Li, T.C., Rogers, A.W., Cooke, I.D. \& Mundy, J. (1990) A morphometric study of the human endometrial stroma during the peri-implantation period. Hum. Reprod. 5, 112-116.

Droesch, K., Navot, D., Scott, R., Kreiner, D., Liu, H.C. \& Rosenwaks, Z. (1988) Transdermal estrogen replacement in ovarian failure for ovum donation. Fert. Steril. 50, 931-934.

Edwards, R.G. \& Fishel, S.B. (1986) Ovulation, fertilization, embryo cleavage and implantation. In Scientific Foundations of Obstetrics and Gynecology, pp. 212224. Eds E. Philipp, J. Barnes \& M. Newton. William Heinemann Medical Books, London.

Finn, C.A. \& Keen, P.M. (1962) Studies on deciduomata formation in the rat. J. Reprod. Fert. 4, 215-216.

Finn, C.A. (1977) The implantation reaction. In Biology' of the Uterus, 2nd edn, pp. 245 308. Ed. R. M. Wynn. Plenum Press, New York.

Finn, C.A. (1985) Uterine responses to the corpus luteum. In The Luteal Phase, pp. 43-59. Ed. S. L. Jeffcote. John Wiley \& Sons Ltd, Chichester.

Fraser, D., Whitehead, M.I., Endacott, J., Morton, J., Ryder, T.A. \& Pryse-Davies, J. (1989) Are fixed-dose oestrogen/progestogen combinations ideal for all HRT users? Br. J. Obstet. Gynaec. 96, 776782.

Graham, R.A., Seif, M.W., Aplin, J.D., Li, T.C., Cooke, I.D., Rogers, A.W. \& Dockery, P. (1990) An endometrial factor in unexplained infertility. Br. Med.J.300, 1428-1431.

Grosser, O. (1910) The development of the egg membranes and the placenta; menstruation. In Manual of Human Embryology, pp. 91-179. Eds J. Keibel, P. Mall \& W. Saunders. Philadelphia and London.

Hertig, A.T., Rock, J. \& Adams, C.E. (1956) A description of 34 human ova within the first seventeen days of development. Am. J. Obstet. Gynec. 98, 435 493.

Hung, T.T., Ribas, D., Tsuiki, A., Preyer, J., Slackman, R. \& Davidson, O.W. (1989) Artificially induced menstrual cycle with natural estradiol and progesterone. Fert. Steril. 51, 968-971. 
Johannisson, E., Parker, R.A., Landgren, B.M. \& Diczfalusy, E. (1982) Morphometric analysis of the human endometrium in relation to peripheral hormone levels. Fert. Steril. 38, 564-571.

Johannisson, E., Landgren, B.M., Rohr, H.P. \& Diczfalusy, E. (1987) Endometrial morphology and peripheral hormone levels in women with regular menstrual cycles. Fert. Steril. 48, 401-408.

Johnson, M. \& Everitt, B. (1984) Implantation and the establishment of the placenta. In Essential Reproduction, 2nd edn, pp. 215-242. Blackwell Scientific Publications, Oxford.

King, R.J.B. \& Whitehead, M.I. (1986) Assessment of the potency of orally administered progestins in women. Fert. Steril. 46, 1062-1066.

Lane, G., Siddle, N.C., Ryder, T.A., Pryse-Davies, J., Kind, R.J.B. \& Whitehead, M.I. (1986) Effects of dydrogesterone on the oestrogenized postmenopausal endometrium. Br. J. Obstet. Gynaec. 93, $55-62$.

Li, T.C., Rogers, A.W., Lenton, E.A., Dockery, P. \& Cooke, I.D. (1987) A comparison between two methods of chronological dating of human endometrial biopsies during the luteal phase, and their correlation with histologic dating. Fert. Steril. 48, 928-932.

Li, T.C., Rogers, A.W., Dockery, P., Lenton, E.A. \& Cooke, I.D. (1988a) A new method of histologic dating of human endometrium in the luteal phase. Fert. Steril. 50, 52-60.

Li, T.C., Dockery, P., Thomas, P., Rogers, A.W., Lenton, E.A. \& Cooke, I.D. (1988b) The effects of progesterone receptor blockade in the luteal phase or normal fertile women. Fert. Steril. 50, 732-742.

Li, T.C. \& Cooke, I.D. (1990a) Outpatient endometrial biopsy: clinical, endocrinologic and histologic consequences. Int. J. Gynaec. Obstet. 31, 35-41.

Li, T.C. \& Cooke, I.D. (1990b) Delayed abdominal pain after outpatient endometrial biopsy in the luteal phase. Int. J. Gynaec. Obstet. 32, 267-268.

Li, T.C., King, H. \& Cooke, I.D. (1990a) The discomfort of outpatient endometrial biopsy in relation to parity and techniques. J. Obstet. Gynaec. 10, 243-247.

Li, T.C., Dockery, P., Rogers, A.W. \& Cooke, I.D. (1990b) A quantitative study of endometrial development in the luteal phase: comparison between women with unexplained infertility and normal fertility. Br. J. Obstet. Gynaec. 97, 576-582.

Li, T.C., Lenton, E.A., Dockery, P. \& Cooke, I.D. (1990c) A comparison of some clinical and endocrinological features between cycles with normal and defective luteal phases in women with unexplained infertility. Hum. Reprod. 5, 805-810.

Lutjen, P., Trounson, A., Leeton, J., Findlay, J., Wood, C. \& Renou, P. (1984) The establishment and maintenance of pregnancy using in vitro fertilization and embryo donation in a patient with primary ovarian failure. Nature, Lond. 307, 174-175.
Lutjen, P.J., Findlay, J.R., Trounson, A.O., Leeton, J.F. \& Chan, L.K. (1986) Effects on plasma gonadotrophins of cyclic steroid replacement in women with premature ovarian failure. J. Clin. Endocrinol. Metab. 62, 419-423.

McLaren, A. (1984) The control of implantation. In In Vitro Fertilization and Donor Insemination, Proceedings of the Twelfth Study Group of the Royal College of Obst. and Gynaec. pp. 13-22. Eds W. Thompson, D. N. Joyce \& J. R. Newton.

Navot, D., Laufer, N., Kopolovic, J., Rabinowitz, R., Birkenveld, A., Lewin, A., Granat, M., Margalioth, E. \& Schenker, J.G. (1986) Artificially induced endometrial cycles and establishment of pregnancies in the absence of ovaries. N. Engl. J. Med. 314, 806-811

Navot, D., Anderson, T.L., Droesch, K., Scott, R.T., Kreiner, D. \& Rosenwaks, Z. (1989) Hormonal manipulation of endometrial maturation. J. Clin. Endo. Metab. 68, 801-807.

Noyes, R.W., Hertig, A.T. \& Rock, J. (1950) Dating the endometrial biopsy. Fert. Steril. 1, 3-25.

Pellicer, A., Matallin, P., Miro, F., Rivera, J. \& Bonilla-Musoles, F. (1989) Progesterone versus dehydrogesterone as replacement therapy in women with premature ovarian failure. Hum. Reprod. 4, $777-781$

Pollard, R.M. \& Finn, C.A. (1972) Ultrastructure of the uterine epithelium during the hormone induction of sensitivity and insensitivity to a decidual stimulus in the mouse. J. Endocrinol. 55, 293-298.

Psychoyos, A. (1961) Nouvelles recherches sur l'ovoimplantation. C.r. hebd. Seanc. Acad. Sci. Paris. 252, 2306-2307.

Rogers, P., Murphy, C., Cameron, I., Leeton, J., Hosie, M., Beaton, L. \& Macpherson, A. (1989) Uterine receptivity in women receiving steroid replacement therapy for premature ovarian failure: ultrastructural and endocrinological parameters. Hum. Reprd. 4, 349-354.

Rosenwaks, Z. (1987) Donor eggs: their application in modern reproductive technologies. Fert. Steril. 47, 895-909.

Salat-Baroux, J., Cornet, D., Alvarez, S., Antoine, J.M., Tibi, C., Mandelbaum, J. \& Plachot, M. (1988) Pregnancies after replacement of frozen-thawed embryos in a donation program. Fert. Steril. 49, 817-821.

Serhal, P.F. \& Craft, 1.L. (1987) Ovum donation-a simplified approach. Fert. Steril. 48, 265-269.

Serhal, P.F. \& Craft, I.L. (1989) Oocyte donation in 61 patients. Lancet. i, 1185-1187.

Steingold, K., Stumpf, P., Kreiner, D., Liu, H.C., Navot, D. \& Rosenwaks, Z. (1989) Estradiol and progesterone replacement regimens for the induction of endometrial receptivity. Fert. Steril. 52, 756-760.

Wilson, E.W. (1969) Alkaline phosphatase in predecidual cells of the human endometrium. $J$. Reprod. Fert. 19, 567-568. 